た.

\section{1. 胃の二重造影時のガス飲用の一方法}

旭川赤十字病院放射線科

宮 森 要・浅坂三五郎・高橋 和弘 吉田 隆雄

従来型二重造影法としては，カテーテルによる空気注 入法. 発泡剂法. バリウムと同時に空気を领用する法等

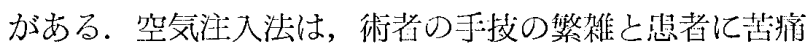
を字えることで，特别の日蛙以外はあまり行なわれない。

また発泡剂は各種とす研究さ机妄く用いられているが， ての欠点として小気泡を発生するととがあるため，乙れ が読影上の障害となり，乙れを排除するために消泡剂の 使用という手数がある。

空父领用法には，患者の訓練が必要で，尖分な㘹父を 送入する事は至難である。乙れらの従来の方法の久点を 除き，比軖的容易にガスの飲用が出来る一方法を試みた。

宮森の発案によって, 各病院に常備されている酸素ガ スボンベを利用し，筆者が考案した集泡カバ一を付属す バリウムカップに酸素を送り，との酸素気泡をバリウム と同時に患者に飲用させ，透視中に送入酸素量を調節す るととによって適量のガスを胃に送気できる利点がある。

第 2 法は，ガス発生源としてェアポンプ（熱带焦等の 柃育用）を使用し，乙の筀氛第 1 治と同じ集泡力バー つきバリウムカップに送った、いづれの方法も，ガス量 調筫は简笚であり，ガス発生源の入手は谷易である。

\section{Subtraction に関する研究（第 4 報）}

北海道大学医学部付属病院放射線部 (部佥 桨" 林 勝教授)

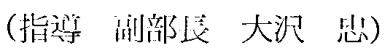
(技们哀定 佳藤 国男)

北川毅, 間瀬 博, 柏木 茂喜

\section{〔緒窨】}

フォトグラフィック・サブトラクションのダリアポジ ティヴ用フィルム及びサブトラクッョン用フィルムとし て複製用フィルムに代えてグラビアフィルム・ウルトラ ソフトの利用を検討したので報告する。

\section{[方法]}

先ずアルミステップによって複製用フィルムとグラビ アフィルム・ウルトラソフト雨者の特性曲線を作成し, 特性，感度を比粉した，次に裕製用フィルムとグラビア フィル・ウルトラソフトのそれぞれについて現像液，現 像条件を変えて 3 種 6 枚のダイアポジティヴ像を作成し， 更にそのダイアポジティヴ像を使ってサブトラクション 像を作成した。

\section{[結果]}

複製用フィルムとグラビアフィルム・ウルトラソフト を比較検討した結果，特性曲線上で両者はほぼ同じ特性， 感度を持ち大きな差違はない。従って，グラビアフィル ム・ウルトラソフトによって良好なダイアポジティヴを 得るのに従来複製用フィルムに対して行なってきた処理 条件をそのまま当てはめて行った。しかし，ダイアボシ ティヴ，サブトララクションの双方にグラビアフィルム， ウルトラソフトを使州した場合の方が，双方に複製用フ ィルムを使川した場合よりむ微細な部分的即ち末俏血管 等の表現力がやや優れている。 また，フィルムベースは 複製用フィルムが約 $0.14 \mathrm{~mm}$ でローラ型自動現像機の口 一ラに卷きついてトラブルを起す伦険性があるのに対し， グラビアフィルム・ウルトラソフトは約 $0.175 \mathrm{~mm}$ でト ラブルを起す心配がなく，目動現像機で処理するのに適 している.

\section{3. 脳血管造影の Subtraction（第 2 報）}

$$
\begin{aligned}
& \text { 旭川赤十字病院 } \begin{array}{l}
\text { 放射線科 } \\
\text { 吉田 隆雄 }
\end{array} \\
& \text { 共同研究者 } \\
& \text { 宮 森 要・浅坂三五郎・高橋 和弘 }
\end{aligned}
$$

さきに，炤和39年日本放射線技術学会北海道支部総合

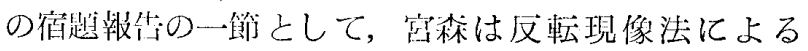
Subtraction を発表したが轻現像法は処理の烦䊒さは もとより，単紨掓影像と同じ階調の反転像を得難いとい う困難に遭遇した。

この困難を解除し, Subtraction が routine の方法と して酒用されるように，今回は複写法による反転像の作 留を試みた。裕年フィルムには, 国内 $\mathrm{A}, \mathrm{B}$ 社製及び外 国C社敒の 3 程のものを使用し, その性能を比較検討し た.

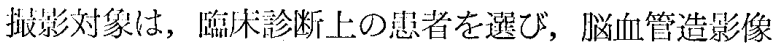
と笔紌撮影上り得た複写像との Subtraction を行なった ところ，乙れに最も適当した複写フィルムは, 国内A社 製のものであった。しかし, 複写時の露光照度及び簬光 時間から観察すると，感度上 $\mathrm{C}, \mathrm{B}, \mathrm{A}$ 順の結果を得た。

複写フィルム法によれば, 複写条件の決定によって, Subtractionは, routine の方法として, 容易に利用でき 得るむのと考えられる。

\section{4. 耳小骨撮影法の検討（第 1 報）}

北沙:道大学矤学部付属狖院 放射線部

$$
\begin{aligned}
& \text { (部 長 若 林 勝) } \\
& \text { (副部長 大沢 忠) }
\end{aligned}
$$

佐藤 国男·千田 昌美·○石川 秀司 